\title{
Effect of Inadequate Design on Cost and Time Overrun of Road Construction Projects in Tanzania
}

\author{
Eradius E. Rwakarehe ${ }^{1}$ and David A. Mfinanga ${ }^{2}$
}

Received January 10, 2013 / Revised September 13, 2013 / Accepted September 24, 2013

\begin{abstract}
Completing road construction projects within the budget and time has been a problem for the Tanzania National Roads Agency (TANROADS); and the major problem highlighted in almost all projects being inadequate design. However, the extent to which inadequate design contributes to both time and cost overruns and its causes remained under-studied. The objective of this study is therefore to determine the extent of the effect of inadequate design, its causes and remedial measures. The methodology used in this study includes reviewing recent projects completion reports, holding roundtable discussions with consultants and TANROADS officials and analyzing the information. Cost and time overruns for the reviewed projects averaged $44 \%$ and $26 \%$ respectively. Similarly, the extents to which inadequate design contributes to cost and time overruns were on average found to be $61 \%$ and $85 \%$ respectively. The overruns are predominantly related to problems that occurred during the design process. To alleviate the problem, TANROADS is advised to improve the management of design projects, enhance the process of reviewing design reports, improve the design process including introducing Road Safety Audit and geometric design manuals, and increase staff to match the work-load.
\end{abstract}

Key Words: Cost-overrun, Time-overrun, Inadequate Highway Design

\section{INTRODUCTION}

\section{A. Background}

The size of the Tanzanian road network is estimated to be around $85,000 \mathrm{~km}$ of which more than two thirds are district and feeder roads that are under the Prime Minister's Office, Regional Administration and Local Government. Tanzania National Roads Agency (TANROADS) is responsible for the remaining 28,000 $\mathrm{km}$ of main road network of which $23,000 \mathrm{~km}(82 \%)$ are unpaved. The paved road network is about $5,000 \mathrm{~km}$ long, of which most are classified as trunk roads. Also about $5,000 \mathrm{~km}$ of the unpaved roads are classified as trunk roads and the remaining $18,000 \mathrm{~km}$ as regional roads. ${ }^{1}$

Tanzania had a remarkable increase in road upgrading projects in the late 1990's and early 2,000's. However, like other countries worldwide, problems related to cost and time overruns of construction projects were common in most of the projects let alone the issues of quality, etc. Under normal circumstances one would expect the probability of both cost and time overruns to be the same as that of completing the project below the cost and time estimate, but unfortunately the opposite is true [1]. This unexpected situation brings about questions that need thorough investigation. According to Kawambwa,

\footnotetext{
${ }^{1}$ Roads Fund Board, "Road Subsector Maintenance Financing and Strategies for year 2007/2008 to year 2011/2012”, Roads Fund Board, Dar es Salaam, 2007.
}

Tanzania has been witnessing cost and time overruns on a number of construction projects. Instead of a project taking two years, it takes more than three years and a project which was initially intended to cost a billion shillings ends up consuming more than double that amount. $^{2}$ The situation seems to be worse in India where studies on construction projects, for example, found that more than $60 \%$ of projects experienced up to $200 \%$ time overrun and $750 \%$ cost overrun [2].

Road construction projects in Tanzania are infamous for time and cost overruns. One of the major common factors highlighted in almost all projects is inadequate design. However, their extents as well as the causes have remained under-studied. It is unfortunate that delays in project implementation mean that the people (road users) and the economy have to wait for the road longer than it is necessary; which in turn limits the growth potential of the economy at large. On the other hand, services provided by road projects serve as input for many other sectors of the economy. Therefore, cost overruns lead to an increase in the capital-output-ratio for the entire economy. Combining these two secondary problems: delays and cost overrun, the result is reduction in the efficiency of the available resources and limited growth potential of the entire economy.

\footnotetext{
2 S. J. Kawambwa, "Opening Speech by the Minister for Infrastructure Development, when Opening the Construction Industry Forum for Year 2008", Arusha, 2008
}

\footnotetext{
1 Assistant Lecturer, Department of Transportation and Geotechnical Engineering, University of Dar es Salaam, Dar es Salaam, Tanzania, eradius@udsm.ac.tz, eraddy2001@yahoo.co.uk (*Corresponding Author)

2 Associate Professor, Department of Transportation and Geotechnical Engineering, University of Dar es Salaam, Dar es Salaam, Tanzania, mfinanga@udsm.ac.tz
} 


\section{B. Research Gap}

Many researches about cost and time overruns on construction projects have already been done. However, most of these researches have investigated the causes of cost and time overruns without paying much attention on both the causes of such problems and the remedial measures; for instance, the cause(s) of inadequate design and the ways to minimize them. These researches include $[3,4,5,6,7,8,9,10]$. Those who went further to suggest the ways of solving the identified problems, for instance, Vidalis and Najafi [9] gave general solutions.

Regarding the extent to which these problems contribute to both cost and time overruns, only Vidalis and Najafi [9] went a mile ahead to establish the extents in the research they did in Florida - US. However, it is the authors' opinions that the extents different problems contribute to cost and time overruns are definitely different when developed and developing countries are compared. Therefore, the motive of this paper is to investigate the causes of inadequate design as well as the extent it contributes to cost and time overruns on road construction project in Tanzania as well as the remedial measures.

\section{Research Objectives}

The objectives of this study were to: (i) establish to what extent inadequate design contributes to cost and time overruns (ii) establish the common types of inadequate design that contribute to cost and time overrun, their causes as well as the solutions (iii) determine the road-design-process gap existing in the current practice in Tanzania.

\section{Scope of the Study}

The study focused on road upgrading projects recently carried out by TANROADS along the country's central corridor. These projects were delivered through the traditional method of design-bid-build. In order to accomplish this work, all factors leading to cost and time overruns were identified. However, studies on the causes and measures to eliminate the identified problems focused on those related to design only. Moreover, due to the nature of the data that were available, it was impossible to separate design changes due to mistakes or omissions and those due to inaccurate estimates (wrong computation of quantities); as a result, they were all treated as inadequate design. The following projects were assessed:

- Mwanza/Shinyanga Border - Tinde Road Upgrading

- Mutukula - Muhutwe Road Upgrading

- Nzega - Isaka (Via Tinde) Road Upgrading

- Shelui - Nzega Road Upgrading

- Singida - Shelui Road Upgrading (Package 1: Singida Town - Iguguno; $34 \mathrm{~km}$ )

- Singida - Shelui Road Upgrading (Package 2: Iguguno - Sekenke Diversion; 42 km)

- Singida - Shelui Road Upgrading (Package 3: Sekenke Diversion - Shelui; 33 km)

\section{E. The State-of-the-Art of Road Design Process}

Road design is one of the stages in the overall highway development process. Historically, design has always occurred in the middle of the process, linking the preceding phase of planning and project development with the subsequent phases of right-of-way acquisition, construction and maintenance [11]. This phase has several activities that differ from one country to another. However, reviewed documents revealed the major activities as feasibility study and preliminary design, and detailed engineering design $[11,12,13,14,15,16,17$, 18]. The sub-activities within the major activities are as described below.

Feasibility Study and Preliminary Design: This involves the analysis of possible solutions to a problem and a recommendation on the best solution to adopt. It is conducted to assist decision-makers in determining whether or not to implement a particular project. According to Arnitis et al. [14], feasibility study of a road project aims to determine the socio-economic needs to implement a specific project, determine the most favourable alignment and to determine optimal structure and engineering solutions and possibilities to implement them. The study contains extensive data related to financial and operational impact and it includes advantages and disadvantages of both the current situation and the proposed plan.

Detailed Engineering Design: This involves review of the alternative designs proposed in the preliminary design so as to select the optimal one on which the detailed design should be based. Those design activities that were carried out during preliminary design are now repeated in a more thorough way. This is accomplished by fixing the final and permanent centreline of the road and at the same time gathering additional physical data needed to prepare the construction plan. After submitting a draft of detailed design, a team comprising specialists in different areas reviews the same while the road safety audit also takes place $[12,13,15,16]$. Comments from the teams for design review and road safety audit are sent to the design consultant (or design team if the work was done in-house) for acting accordingly. The draft design is changed accordingly to produce the final detailed engineering design documents.

\section{RESEARCH METHODOLOGY}

\section{A. Overview of the Methodology}

The methodology used to accomplish this study involved several activities. The first activity involved undertaking a comprehensive literature review of similar problems in different countries. The second activity included identifying the projects to be studied and finally carrying out the study itself. Review of the information given by TANROADS revealed that most of the completed upgrading projects were along the central corridor. Projects along other corridors were either maintenance projects or in progress. The next step involved identifying all recently completed road upgrading projects along the case study corridor, 
reviewing their project completion reports and project files, interviewing respective projects engineers on matters that were not clear in the reports and holding roundtable discussions with design consultants and officials in the design section at TANROADS headquarters. The analysed projects were those delivered by the traditional design-bid-build method that typically consists of discrete feasibility study and preliminary design, detailed design, construction and operation phases (Figure I). The data analysis on the extent of cost and time overrun were done quantitatively while qualitative analysis method was employed for the causes of cost and time overruns; and the causes of inadequate design. The questionnaires for roundtable discussions were prepared and sent to a few selected consultants and Head of design department at TANROADS for comments. Improvements were then done accordingly so as to get the final ones that were used during the roundtable discussion.

For qualitative findings, the reliability of the results was tested by comparing responses from consultants and TANROADS officials whereas for the quantitative part; the results were tested by comparing with other studies done within the country. The validity of the results was further verified by studying all projects along the case study corridor and by involving a good number of experts during the roundtable discussion.

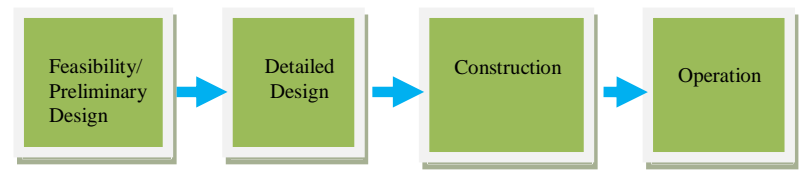

FIGURE I

Traditional Project DeVelopment Phases

\section{B. Road-Design-Process Gap Existing in the Current Practice in Tanzania}

The state-of-the-art of road design process was first established through extensive review of literature. The current practices in Tanzania were identified through roundtable discussions with consulting companies and officials in the design section at TANROADS headquarters. The views obtained from consulting/design companies and TANROADS officials were analysed and were compared with the state-of-the-art in order to identify the gaps.

\section{Common Types of Inadequate Design that Contribute to Cost and Time Overrun and their Causes}

Project completion reports and project files were carefully reviewed in order to identify the types of inadequate design encountered during projects execution. In addition, roundtable discussions with several TANROADS officials from the design section and consultants were held in order to determine the causes of such inadequate designs and ways of eliminating them. Discussion with TANROADS officials were held for the second time in order to clarify the issues raised by consultants against them.
The results of the discussions were then analysed in great detail. Based on the outcome of the literature review, projects completion reports review and the discussions, a set of pertinent issues were identified and studied further. These pertinent issues were factors that were thought to have profound effects on the causes of cost and time overruns of road construction projects. These factors in turn were used to establish the ways of eliminating or reducing the problem.

\section{Time Overrun}

Time overrun was treated as the time difference between the actual and the initially planned (expected) dates of completion [19, 20]. The original completion dates for individual projects as well as the actual completion dates were extracted from respective project completion reports. The difference between the two dates is the time overrun and the percentage ratio of this difference to the original contract duration was used to define the time overrun rate.

In order to extract the overrun caused by inadequate design, a careful study of the analysis done by the project supervising consultants on granting the time extension requested by the contractor was done. The key documents on this matter were contractor's letters requesting for extension as well as consultant's letters granting the extension. Normally contractor's letters included every reason for requesting for extension and the number of days for each individual problem. The consultant could either grant the whole requested time, reduce or reject it; and in any case the reason(s) was/were stated in the letters. By reading these letters, problems associated with inadequate design could be separated from others. Therefore, out of the total overrun duration, the extension time granted as a result of design problems was separated from others and used to determine the overrun rate due to inadequate design.

\section{E. Cost Overrun}

Cost overrun is generally expressed as the difference between the final cost of the project and the contract award amount [20]. In most of the literature reviewed, the major causes of cost overrun are additional works and the related preliminaries including increase in cost of insurance as a result of increased works, changes in original design and/or scope, claims due to cost escalations and interest on delayed payments $[3,4,5,6$, $17,18,20]$. On reviewing documents used in this study (project completion reports and project files), the same causes were found.

In analysing the cost overrun due to inadequate design, any excess amount due to change in design while keeping the scope intact, addition of omitted works, inaccurate estimates of quantities and their cost related preliminaries was considered as overrun due to inadequate design. However, cost escalation, which is also part of the estimate, was not considered as part of poor estimates because of its unpredictability as some of its driving factors may change while construction is in progress. 
However, one would argue that some of the payments might be delayed while the client is struggling to look for extra money for additional works in which if there was no additional works the delay would not have happened. By virtue of this argument, it is true that some of the claims due to delayed payments may have their root causes related to inadequate design and therefore not clients' faulty. However, due to the difficulty in separating the two scenarios, anything related to interest has been treated as client's faulty.

The percentage difference between the original and actual costs of different projects were determined and used to calculate their respective cost overrun rate. In order to determine the overrun rate emanating from design, the ratio of cost overrun due to inadequate design to the original contract price was used. Consultant's letters to the client informing him of the needs for extra funds and the reasons, were the good sources of information used to separate causes of cost overrun due to inadequate design from others.

\section{DATA COLLECTION AND ANALYSIS}

\section{A. Introduction}

As pointed out in chapter two, the data for this study were gathered through reviewing completion reports and project files of recently completed projects and holding roundtable discussions with consultants and TANROADS officials. The data collected and the matters discussed during roundtable discussions can be seen in appendices.

\section{B. Summarised projects data}

In this section, findings for each project are presented under different categories of historical data, time and cost variations and the reasons in Tables I to III. The information in this section was gathered from TANROADS office [21, 22, 23, 24, 25, 26, 27].

TABLE I

PROJECTS' INFORMATION

\begin{tabular}{|c|c|c|c|c|c|c|}
\hline Project & $\begin{array}{l}\text { Road } \\
\text { Length } \\
(\mathrm{km})\end{array}$ & $\begin{array}{c}\text { Detailed } \\
\text { Design } \\
\text { Year } \\
\end{array}$ & Design Company/ Consultant & $\begin{array}{c}\text { Start of } \\
\text { Construction } \\
\text { Works } \\
\end{array}$ & Contractor & $\begin{array}{c}\text { Supervising } \\
\text { Consultant }\end{array}$ \\
\hline $\begin{array}{c}\text { Mwanza/Shinyanga } \\
\text { Border - Tinde }\end{array}$ & 96 & 1991 & $\begin{array}{l}\text { Beca Worley International, } \\
\text { Design Partnership (T) Ltd \& } \\
\text { Parkman Consultants Ltd }\end{array}$ & 2004 & Grinaker-LTA & Louis Berger SA \\
\hline Nzega - Isaka & 73 & 1991 & $\begin{array}{l}\text { Beca Worley International, } \\
\text { Design Partnership (T) Ltd \& } \\
\text { Parkman Consultants Ltd }\end{array}$ & 2004 & Grinaker-LTA & $\begin{array}{l}\text { HYDROARCH S.R.I. \& } \\
\text { Design Partnership (T) } \\
\text { Ltd }\end{array}$ \\
\hline Mutukula - Muhutwe & 112 & 1992 & M-Konsult Limited & 2001 & $\begin{array}{l}\text { China Henan Int'nal } \\
\text { Cooperation Group } \\
\text { Company Ltd }\end{array}$ & BCEOM \\
\hline Shelui - Nzega & 112 & 1994 & RITES \& M-Konsult JV & 2002 & $\begin{array}{c}\text { China Geo-engineering } \\
\text { Company Ltd }\end{array}$ & $\begin{array}{c}\text { Norconsult } \\
\text { International AS }\end{array}$ \\
\hline $\begin{array}{c}\text { Singida - Shelui } \\
\text { (Package 1: Singida } \\
\text { Town - Iguguno) }\end{array}$ & 34 & 1996 & RITES \& M-Konsult JV & 2005 & $\begin{array}{l}\text { China Henan Int'nal } \\
\text { Cooperation Group } \\
\text { Company Ltd }\end{array}$ & $\begin{array}{l}\text { Roughton International } \\
\text { \& Dataconsult }\end{array}$ \\
\hline \begin{tabular}{c|} 
Singida - Shelui \\
(Package 2: Iguguno \\
- Sekenke Diversion)
\end{tabular} & 42 & 1996 & RITES \& M-Konsult JV & 2005 & $\begin{array}{l}\text { China Henan Int'nal } \\
\text { Cooperation Group } \\
\text { Company Ltd }\end{array}$ & $\begin{array}{l}\text { Dar Al-Handash (Shair } \\
\text { and Partners) }\end{array}$ \\
\hline $\begin{array}{c}\text { Singida - Shelui } \\
\text { (Package 3: Sekenke } \\
\text { Diversion - Shelui) }\end{array}$ & 33 & 1996 & RITES \& M-Konsult JV & 2005 & $\begin{array}{l}\text { China Henan Int'nal } \\
\text { Cooperation Group } \\
\text { Company Ltd }\end{array}$ & $\begin{array}{l}\text { BCEOM \& } \\
\text { M-Konsult }\end{array}$ \\
\hline
\end{tabular}

TABLE II

SUMMARY OF TIME OVERRUN

\begin{tabular}{|c|c|c|c|c|c|c|c|c|c|c|}
\hline \multirow[b]{2}{*}{ Project Name } & \multicolumn{10}{|c|}{ SUMMARY OF TIME OVERRUN } \\
\hline & 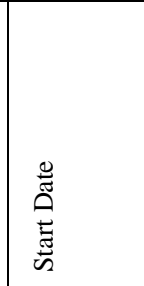 & 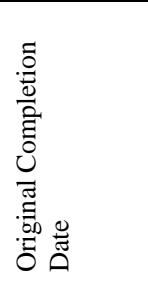 & 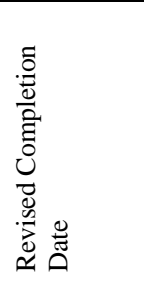 & 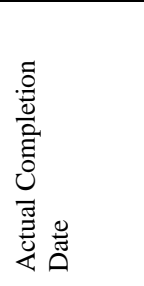 & 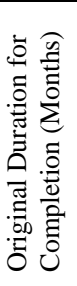 & 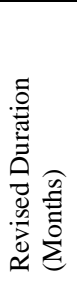 & 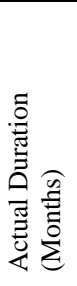 & 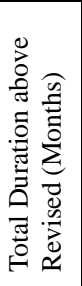 & 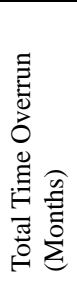 & 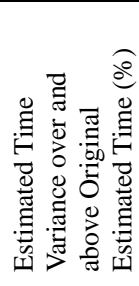 \\
\hline $\begin{array}{l}\text { Mwanza/Shinyanga Border - } \\
\text { Tinde }\end{array}$ & $11 / 02 / 2004$ & $10 / 02 / 2006$ & $30 / 06 / 2007$ & $30 / 05 / 2007$ & 24 & 40.7 & 39.7 & -1 & 15.7 & 65 \\
\hline Nzega - Isaka & $26 / 05 / 2004$ & $25 / 05 / 2006$ & $25 / 05 / 2008$ & $15 / 02 / 2007$ & 24 & 48 & 32.7 & -15.3 & 8.7 & 36 \\
\hline Mutukula - Muhutwe & $15 / 03 / 2001$ & $17 / 12 / 2003$ & $30 / 09 / 2004$ & $29 / 09 / 2004$ & 33 & 42.5 & 42.5 & 0 & 9.5 & 29 \\
\hline Shelui - Nzega & $12 / 08 / 2002$ & $16 / 02 / 2005$ & $10 / 08 / 2005$ & $07 / 07 / 2005$ & 30 & 35.8 & 34.8 & -1 & 4.8 & 16 \\
\hline Singida - Shelui (Package 1) & $23 / 05 / 2005$ & $22 / 11 / 2007$ & $22 / 10 / 2008$ & $22 / 10 / 2008$ & 30 & 41 & 41 & 0 & 11 & 37 \\
\hline Singida - Shelui (Package 2) & $12 / 05 / 2005$ & $11 / 11 / 2007$ & - & $11 / 11 / 2007$ & 30 & - & 30 & - & 0 & 0 \\
\hline Singida - Shelui (Package 3) & $11 / 02 / 2005$ & $10 / 02 / 2008$ & - & $15 / 01 / 2008$ & 36 & - & 35.2 & - & -0.8 & -2 \\
\hline \multicolumn{11}{|c|}{ Average (\%) 26} \\
\hline Standard Deviation $(\%)$ & & & & & & & & & & 23 \\
\hline
\end{tabular}


TABLE III

SUMMARY OF COST OVERRUN

\begin{tabular}{|c|c|c|c|c|c|c|c|c|c|}
\hline Project & 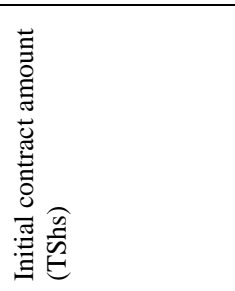 & \multicolumn{2}{|c|}{ (2) } & \multicolumn{2}{|l|}{ 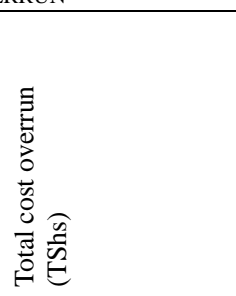 } & \multicolumn{2}{|c|}{ 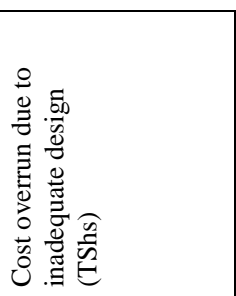 } & \multicolumn{2}{|c|}{ 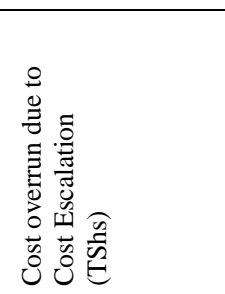 } \\
\hline Mwanza/Shinyanga Border - Tinde & $28,937,974,278$ & \multicolumn{2}{|c|}{$53,494,952,436$} & \multicolumn{2}{|c|}{$24,556,978,158$} & \multicolumn{2}{|c|}{$14,991,713,167$} & \multicolumn{2}{|r|}{$9,565,264,991$} \\
\hline Nzega - Isaka & $20,613,377,764$ & \multicolumn{2}{|c|}{$40,626,236,125$} & \multicolumn{2}{|c|}{$20,012,858,361$} & \multicolumn{2}{|c|}{$12,531,872,075$} & \multicolumn{2}{|r|}{$7,480,986,286$} \\
\hline Mutukula - Muhutwe & $13,835,786,505$ & \multicolumn{2}{|c|}{$17,359,832,309$} & \multicolumn{2}{|c|}{$3,524,045,804$} & \multicolumn{2}{|c|}{$2,156,281,022$} & \multicolumn{2}{|r|}{$1,367,764,782$} \\
\hline Shelui - Nzega & $20,723,844,565$ & \multicolumn{2}{|c|}{$22,610,465,125$} & \multicolumn{2}{|c|}{$1,886,620,560$} & \multicolumn{2}{|c|}{$1,204,690,157$} & \multicolumn{2}{|r|}{$501,140,498$} \\
\hline $\begin{array}{l}\text { Singida - Shelui (Package 1: } \\
\text { Singida Town - Iguguno) }\end{array}$ & $13,581,357,036$ & \multicolumn{2}{|c|}{$20,533,130,881$} & \multicolumn{2}{|c|}{$6,951,773,845$} & \multicolumn{2}{|r|}{$3,207,529,433$} & \multicolumn{2}{|r|}{$1,179,913,299$} \\
\hline $\begin{array}{l}\text { Singida - Shelui (Package 2: Iguguno } \\
\text { - Sekenke Diversion) }\end{array}$ & $12,554,132,295$ & \multicolumn{2}{|c|}{$14,435,489,444$} & \multicolumn{2}{|c|}{$1,881,357,149$} & & $605,887,002$ & & $275,470,148$ \\
\hline $\begin{array}{l}\text { Singida - Shelui (Package 3: } \\
\text { Sekenke Diversion - Shelui) }\end{array}$ & $15,934,800,143$ & $20,457,07$ & 3,990 & 4,52 & 278,847 & & $170,911,873$ & & $2,351,366,974$ \\
\hline Average $(\%)$ & & & & & & & & & \\
\hline Standard Deviation $(\%)$ & & & & & & & & & \\
\hline Project & 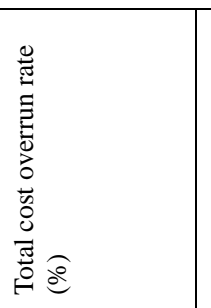 & 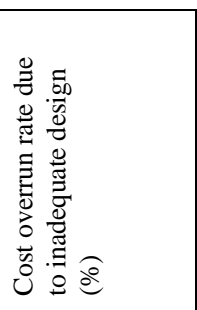 & 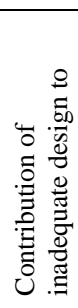 & & 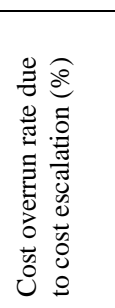 & & 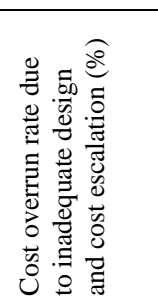 & & 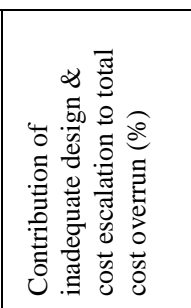 \\
\hline Mwanza/Shinyanga Border - Tinde & 85 & 52 & & 61 & & 33 & & 85 & 100 \\
\hline Nzega - Isaka & 97 & 61 & & 63 & & 36 & & 97 & 100 \\
\hline Mutukula - Muhutwe & 26 & 16 & & 61 & & 10 & & 26 & 100 \\
\hline Shelui - Nzega & 9 & 6 & & 64 & & 2 & & 8 & 89 \\
\hline $\begin{array}{l}\text { Singida - Shelui (Package 1: } \\
\text { Singida Town - Iguguno) }\end{array}$ & 51 & 24 & & 46 & & 9 & & 33 & 65 \\
\hline $\begin{array}{l}\text { Singida - Shelui (Package 2: Iguguno } \\
\text { - Sekenke Diversion) }\end{array}$ & 15 & 13 & & 85 & & 2 & & 15 & 100 \\
\hline $\begin{array}{l}\text { Singida - Shelui (Package 3: } \\
\text { Sekenke Diversion - Shelui) }\end{array}$ & 28 & 13 & & 48 & & 15 & & 28 & 100 \\
\hline Average (\%) & 44 & 26 & & 61 & & 15 & & 42 & 93 \\
\hline Standard Deviation (\%) & 32 & 20 & & 12 & & 13 & & 32 & 12 \\
\hline
\end{tabular}

\section{DISCUSSION OF THE RESULTS}

\section{A. Summary Discussion on Cost and Time Overrun}

In reviewing project completion reports and project files of the seven completed projects, the following factors were identified as the causes of cost and time overrun of road construction projects.

- Inadequate design

- Increase in cost escalation beyond original estimate (Affects cost overrun only)

- Change in the scope of the project

- Change in government policies e.g. Ban on inclusion of contingencies in the project cost estimates

- Delay in payment to contractors which results in interests

- Inclement weather (Affects only time overrun)

The first two were identified to be dominant as they appeared in all projects. Most of the identified causes match with those found in most literature $[3,4,5,6,7,8$, $9,10]$. However, the problems of supply of materials and availability of equipment which are mentioned by Moris [3] and Swaminathan ${ }^{3}$ do not feature in this study. Table IV shows the frequency by which each factor appeared in the studied projects.

In carrying out the study, it was found that all reviewed seven projects had cost overrun. This is in line with the report by the Controller and Auditor General on performance audit of road works in Tanzania where all the 10 audited projects had both cost and time overruns. ${ }^{4}$ In this study, the total cost overrun rate was found to range from $9 \%$ to $97 \%$ with an average of $44 \%$ and standard deviation of $32 \%$ while the cost overrun due to inadequate design ranges from $6 \%$ to $61 \%$ with $26 \%$ average and $20 \%$ standard deviation. The extent to which

\footnotetext{
${ }^{3}$ A. K. Swaminathan, A. Bandyopadhyay, R. Rohatgi, "Indian Road Construction Industry: Capacity Issues, Constraints \& Recommendations", New Delhi, New Delhi, 2007.

${ }^{4}$ Controller \& Auditor General - Tanzania, "Performance Audit Report on Road Works", Controller and Auditor General Office, Dar es Salaam, 2010.
} 
inadequate design contributes (as a percentage) to total cost overrun ranges from $46 \%$ to $85 \%$ with $61 \%$ average and $12 \%$ standard deviation (refer to Table III). The cost overrun due cost escalation ranges from $2 \%$ to $36 \%$ with $15 \%$ and $13 \%$ as an average and standard deviation respectively. From these figures, it is clear that inadequate design and cost escalation are not only common factors but also the greatest contributing factors towards cost overrun. If measures are taken to improve design and cost escalation estimation (as recommended in section five), the cost overrun problem is likely to be eliminated as in most of the reviewed projects, cost overrun were due to only these two factors (refer to Table III).

On the other hand, the time overrun rate ranges from $-2 \%$ to $65 \%$ with an average of $26 \%$ and standard deviation of $22 \%$. The time overrun due to inadequate design ranges from $13 \%$ to $65 \%$ with $32 \%$ and $18 \%$ as an average and standard deviation respectively. The extent to which inadequate design contributes (as a percentage), to total time overrun ranges from $46 \%$ to $100 \%$ with $85 \%$ average and $21 \%$ standard deviation (refer to Table V). This means that $85 \%$ of the time overrun is likely to be eliminated by improving the design aspect only. The remaining $15 \%$ is contributed by other factors; and these would keep the overrun rate at $4.8 \%$ on average.
Another factor noted on these figures is the significant difference between cost and time overrun rates. This is mostly due to the increase in cost escalation beyond the initial estimate. While cost escalation affects the cost overrun, time overrun is free from it. Moreover, it should be noted that in a situation whereby all other factors remain constant, the cost overrun rate is always greater than time overrun rate for the reason that additional works normally do not suffer mobilisation time as they are always introduced while the project is in progress.

It was also noted that the contractor for projects Mwanza/Shinyanga Border - Tinde and Nzega - Isaka was the best in terms of contractors' efficiency measured in work-done per month (refer Table VI). On average, this contractor could deliver the work worth U\$ 1,188,015 per month while the average for other projects is U\$ 506,911 per month. Probably, this is the reason why the project for Nzega - Isaka was completed 16 months before the end of the revised contract period. However, it should be noted that these projects were done at different times; therefore, the costs have been converted into U\$ Dollars using appropriate exchange rates in order to reduce the effect of inflation.

TABLE IV

OCCURRENCE OF FACTORS CAUSING COST AND TIME OVERRUN

\begin{tabular}{|c|c|c|c|c|c|c|}
\hline \multirow[b]{2}{*}{ Project } & \multicolumn{6}{|c|}{ Factors } \\
\hline & 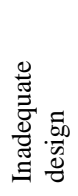 & 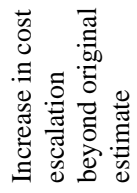 & 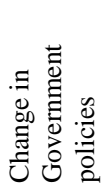 & 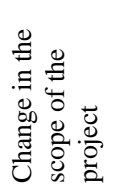 & 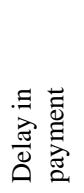 & 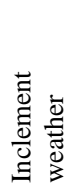 \\
\hline Mwanza/Shinyanga Border - Tinde & $\sqrt{ }$ & $\sqrt{ }$ & $\sqrt{ }$ & & & \\
\hline Nzega - Isaka & $\sqrt{ }$ & $\sqrt{ }$ & $\sqrt{ }$ & & & \\
\hline Mutukula - Bukoba - Muhutwe & $\sqrt{ }$ & $\sqrt{ }$ & $\sqrt{ }$ & & & \\
\hline Shelui - Nzega & $\sqrt{ }$ & $\sqrt{ }$ & $\sqrt{ }$ & & $\sqrt{ }$ & $\sqrt{ }$ \\
\hline Singida - Shelui (Package 1:Singida Town - Iguguno) & $\sqrt{ }$ & $\sqrt{ }$ & & $\sqrt{ }$ & & \\
\hline Singida - Shelui (Package 2: Iguguno - Sekenke Diversion) & $\sqrt{ }$ & $\sqrt{ }$ & & & & \\
\hline Singida - Shelui (Package 3: Sekenke Diversion - Shelui) & $\sqrt{ }$ & $\sqrt{ }$ & & & & \\
\hline Total frequency of occurrences & 7 & 7 & 4 & 1 & 1 & 1 \\
\hline
\end{tabular}

TABLE V

SUMMARY OF TIME OVERRUN AND OVERRUN RATES

\begin{tabular}{|c|c|c|c|c|c|c|}
\hline Project & 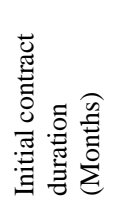 & 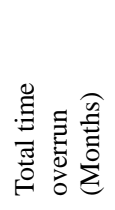 & 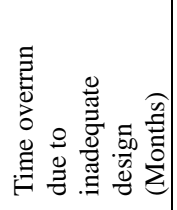 & 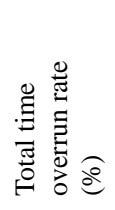 & 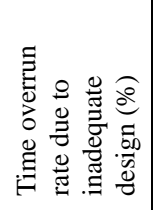 & 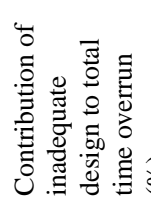 \\
\hline Mwanza/Shinyanga Border - Tinde & 24 & 15.7 & 15.7 & 65 & 65 & 100 \\
\hline Nzega - Isaka & 24 & 8.7 & 8.7 & 36 & 36 & 100 \\
\hline Mutukula - Muhutwe & 33 & 9.5 & 9.5 & 29 & 29 & 100 \\
\hline Shelui - Nzega & 30 & 4.8 & 3.8 & 16 & 13 & 79 \\
\hline Singida - Shelui (Package 1:Singida Town - Iguguno) & 30 & 11 & 5 & 37 & 17 & 46 \\
\hline Singida - Shelui (Package 2: Iguguno - Sekenke Diversion) & 30 & 0 & 0 & 0 & - & - \\
\hline Singida - Shelui (Package 3: Sekenke Diversion - Shelui) & 36 & -0.8 & 0 & -2 & - & - \\
\hline Average $(\%)$ & & & & 26 & $32 *$ & $85^{*}$ \\
\hline Standard deviation $(\%)$ & & & & 22 & 18 & 21 \\
\hline
\end{tabular}

*Despite that there were design deficiencies in the last two projects, determination of the average and standard deviation for time overrun due to inadequate design did not include them as there was no time overrun. 
TABLE VI

BASIC INFORMATION ON PROJECTS COST AND TIME

\begin{tabular}{l|c|c|c|c|c|c|c}
\hline Project Name & $\begin{array}{c}\text { Total Project } \\
\text { Cost (TSh) }\end{array}$ & $\begin{array}{c}\text { Exchange Rate } \\
\text { Value } \\
\text { (TShs:USD) }\end{array}$ & $\begin{array}{c}\text { Project Cost } \\
\text { (USD) }\end{array}$ & $\begin{array}{c}\text { Road Length } \\
(\mathrm{km})\end{array}$ & $\begin{array}{c}\text { Revised } \\
\text { Project } \\
\text { Duration } \\
\text { (Months) }\end{array}$ & $\begin{array}{c}\text { Actual Project } \\
\text { Duration } \\
\text { (Months) }\end{array}$ & $\begin{array}{c}\text { Work-done } \\
\text { (Cost in } \\
\text { USD/Month) }\end{array}$ \\
\hline $\begin{array}{l}\text { Mwanza/Shinyanga Border - } \\
\text { Tinde }\end{array}$ & $53,494,952,436$ & 1,090 & $49,077,938$ & 96 & 40.7 & 39.7 & $1,236,220$ \\
\hline Nzega - Isaka & $40,626,236,125$ & 1,090 & $37,271,776$ & 73 & 48 & 32.7 & $1,139,810$ \\
\hline Mutukula - Muhutwe & $17,359,832,309$ & 876 & $19,817,160$ & 112 & 42.5 & 42.5 & 466,286 \\
\hline Shelui - Nzega & $22,610,465,125$ & 966 & $23,406,279$ & 112 & 35.8 & 34.8 & 672,594 \\
\hline Singida - Shelui (Package 1) & $20,533,130,881$ & 1,120 & $18,333,153$ & 34 & 41 & 41 & 447,150 \\
\hline Singida - Shelui (Package 2) & $14,435,489,444$ & 1,120 & $12,888,830$ & 42 & 30 & 30 & 429,628 \\
\hline Singida - Shelui (Package 3) & $20,457,078,990$ & 1,120 & $18,265,249$ & 33 & 35.2 & 35.2 & 518,899 \\
\hline Average & & & & & 701,512 \\
\hline Standard deviation
\end{tabular}

TABLE VII

OCCURRENCE OF INADEQUATE DESIGN TYPES

\begin{tabular}{l|c|c|c|c|c|c|c|c|c|c|c|c|c|c|c}
\hline \multirow{2}{*}{ Project } & \multicolumn{9}{|c|}{ Type of Inadequate Design } \\
& 1 & 2 & 3 & 4 & 5 & 6 & 7 & 8 & 9 & 10 & 11 & 12 & 13 & 14 & 15 \\
\hline Mwanza/Shinyanga Border - Tinde & $\sqrt{ }$ & $\sqrt{ }$ & $\sqrt{ }$ & $\sqrt{ }$ & $\sqrt{ }$ & $\sqrt{ }$ & $\sqrt{ }$ & & & & $\sqrt{ }$ & $\sqrt{ }$ & & & \\
\hline Nzega - Isaka & $\sqrt{ }$ & $\sqrt{ }$ & $\sqrt{ }$ & $\sqrt{ }$ & $\sqrt{ }$ & $\sqrt{ }$ & & $\sqrt{ }$ & & & & & & & $\sqrt{ }$ \\
\hline Mutukula - Muhutwe & $\sqrt{ }$ & $\sqrt{ }$ & $\sqrt{ }$ & & $\sqrt{ }$ & & & $\sqrt{ }$ & & & & & & & \\
\hline Shelui - Nzega & $\sqrt{ }$ & $\sqrt{ }$ & $\sqrt{ }$ & $\sqrt{ }$ & $\sqrt{ }$ & & & & & & & & & & \\
\hline Singida - Shelui (Package 1) & $\sqrt{ }$ & $\sqrt{ }$ & $\sqrt{ }$ & $\sqrt{ }$ & & & $\sqrt{ }$ & & & $\sqrt{ }$ & & & $\sqrt{ }$ & & \\
\hline Singida - Shelui (Package 2) & $\sqrt{ }$ & $\sqrt{ }$ & $\sqrt{ }$ & $\sqrt{ }$ & $\sqrt{ }$ & & $\sqrt{ }$ & $\sqrt{ }$ & $\sqrt{ }$ & & & & & & \\
\hline Singida - Shelui (Package 3) & $\sqrt{ }$ & $\sqrt{ }$ & $\sqrt{ }$ & $\sqrt{ }$ & & $\sqrt{ }$ & & & $\sqrt{ }$ & & & & & $\sqrt{ }$ & \\
\hline Total frequency of occurrences & 7 & 7 & 7 & 6 & 5 & 3 & 3 & 3 & 2 & 1 & 1 & 1 & 1 & 1 & 1 \\
\hline
\end{tabular}

\section{B. Types of Inadequate Design}

Since one of the major objectives of this study was to find ways of getting rid of inadequate design problem, it was necessary to split further the types of inadequate designs in order to make them easier to find the solution(s) for each design problem. Therefore, through reading project completion reports for individual projects, and other documents in the respective project files, the following types of inadequate design were observed. Table VII shows the frequency by which each inadequate design type appeared in the seven projects studied. The numbers appearing on the second row from the top represent the inadequate design types in the same order as they are listed below.

1. Poor topographical survey

2. Inadequate geotechnical/materials investigation

3. Inaccurate quantity estimates (proper design but wrong computation of quantities)

4. Provision of inadequate size and number of culverts

5. Omission of bus bays

6. Inappropriate provision of drainage ditches

7. Improper investigation of soundness of drainage structures

8. Omission of vehicular and pedestrians' access

9. Improper design of surfacing layer

10. Improper estimate of height of embankment

11. Lack or inadequate provision for alternative route during construction

12. Wrong/inappropriate choice of the route

13. Omission of embankment protection works
14. Improper geometric design of structures built on curves

15. Inconsistent camber provision

Unlike in reviewed literature, these types of inadequate design have been further split-up in order to identify the measures to be taken to eliminate/mitigate them. It should be noted that the first three types appeared in all of the seven projects. This means that whoever is carrying out road design, the first three elements should be looked at with hawkish eyes for better design output. It should also be noted that though other inadequate design types may not appear so frequently, their contribution to both cost and time overruns may be significantly large. However, establishment of this fact is beyond the scope of this study.

\section{Road-Design-Process Gap Existing in Current Practice in Tanzania}

Through discussions held with both TANROADS officials and consultants and upon reviewing projects reports; it was found that the major gaps existing in the road design process are the lack of Road Safety Audit (RSA) step in the design sequence, lack or inadequate review of design reports and non existence of road geometric design manual. Most of the problems observed especially omission of some works related to road users' safety would not have occurred had RSA been conducted at the design stage. Other omissions are due to the lack of a geometric design manual that would have also served as both the checklist and guidance to the designer. For instance, the kind of embankment protection works and 
geometric design of structures built on curves, which were observed to be either omitted or improperly designed are expected to be clearly stipulated in the design manual.

Another major problem observed is that it usually takes longer for construction works to start after the design work has been completed. As the authors were informed by TANROADS officials, the design review normally does not involve fieldwork regardless of the time that had elapsed since design. On some of the projects, the time elapse between design and the start of construction work is accompanied by substantial field changes that would demand a complete new design; but in most cases, TANROADS only reviews the cost to incorporate inflation. This is thought to be the major contributory factor to the mismatch between the situation in design documents and the actual site condition.

Moreover, the rainfall data that are essential for design of drainage facilities are either not available or inadequate. In most of the reviewed projects, the designed drainage facilities were inadequate and in some projects, the already constructed culverts were removed after they were overtopped; and appropriate ones were re-installed. This happened while construction was still in progress.

\section{Causes of Inadequate Design}

The list of the causes of inadequate design was compiled as a result of the roundtable discussions conducted with consultants and TANROADS officials together with information in the project documents. Each type of inadequate design identified from project documents was linked with the information gathered from the discussions in order to come up with the factor that caused it. All of the causes were found to match with the information gathered from both roundtable discussions except corruption, which was not agreed by TANROADS officials. The authors were not surprised by such objection, as it was not likely for TANROADS to accept being involved in corruption.

The factors identified are:

- Technical incompetence of both client's and consultants' staff: Some of client's staff are not experienced enough to review design documents submitted by consultants and as a result poor designs are likely to be approved. On the other hand, some consultants are engaging semi-skilled personnel to carry out design works.

- Lack of RSA activity in the design sequence

- Inadequate management of design projects by the client; especially inadequate time to review design documents and inadequate Terms of Reference for design review

- The use of experience (rule-of-thumb) instead of principles

- Inappropriate staffing level

- Political pressure

- Lack of road geometric design manual

- Use of outdated designs

\section{- Perceived corruption}

Detailed description of these factors can be found in Appendices 3 and 4.

\section{CONCLUSIONS AND RECOMMENDATIONS}

\section{A. Conclusions}

Completing road construction projects on time and within budget has been a problem for the road agency, TANROADS, in Tanzania. The main conclusions drawn from the study reported in this paper are as follows:

- The total cost and time overrun rates on reviewed projects are on average of $44 \%$ and $26 \%$ respectively. However, the cost and time overrun rates due to inadequate design averages $26 \%$ and $32 \%$ respectively and the extent to which inadequate design contributes, as a percentage, to cost and time overruns is $61 \%$ and $85 \%$ respectively.

- All time overruns observed were due to additional construction works and inadequate designs.

- The major road-design-process gaps in Tanzania observed in this study are the lack of RSA activity in the design process together with the lack of road geometric design manual that would also serve as the checklist and guidance to the designers. Most of the problems observed, especially omission of some works related to road-users' safety would not have occurred had RSA been conducted at the design stage.

- It has been found that routine design review is either not done at all or inadequately done and field verification of designs prepared by consultants is not done at all. It was also found that TANROADS lacks the capacity for design review, resulting in design variations during construction and consequently time and cost overruns.

- On the studied projects, cost and time overruns were predominantly related to problems that occurred during the design process prior to construction. These include errors and omissions of some works and key costs in the BoQ at the design stage, inadequate geotechnical/materials investigation, poor topographical survey, inadequate determination of number and/or size of drainage facilities and problems in identifying the scope of work to be done during project development.

- Cost escalation is ranked the second factor contributing to cost overrun after inadequate design. The matter became even worse when price contingency that used to cater for cost escalation was not allowed to be included in contract estimates following Justice Warioba's report on corruption. Although it has now been allowed to be included in cost estimation, budgeting for it is still a big challenge to design consultants. 


\section{B. Recommendations}

In order to improve the road design process at TANROADS, the following are the recommendations:

- Review efforts should strategically focus on areas of design that had been particularly problematic especially geotechnical/materials investigation, topographical survey and drainage structures. TANROADS needs to develop a mechanism to reduce the design problems that are repeatedly occurring on several projects.

- The methods used to carry out design of drainage facilities should follow principles (design standards) instead of experience and where possible TANROADS should have a database of design information especially rainfall data. Moreover, road geometric design manual should be developed in order to help consultants and client's staff to be aware of the standards. This would also solve the current problem whereby several design documents from anywhere else, are being used or referred to by consultants in design contracts.

- There should be a proper management of design projects carried out by consultants. TANROADS should have counterparts on site in order to ensure that design is always conducted as per the contract, all design methods are followed accordingly and skilled personnel mentioned in the design tender documents are available for carrying out the exercise. An acceptable replacement of consultant's personnel should be done only under the approval of the client. However, in order to achieve this, TANROADS should employ more engineers to match with the available work-load.

- TANROADS should engage independent consultants to review designs done by other consultants. This will address the problem of laxity in reviewing design reports and lack of capacity on the client's side.

- TANROADS should introduce RSA at the design stage as most of observed safety problems that are rectified during construction as additional works would have been avoided had RSA been conducted in design stage.

- TANROADS' economists or selected independent consultants should carry out a study and come up with cost escalation estimation tool that would serve as a guide to design consultants.

- Projects whose design seems to be outdated should be re-designed afresh before calling for tendering. This will help to incorporate any field changes that occurred after the initial design.

- Regarding inadequate design types, though some of them may not appear as frequently in projects, their contribution to both cost and time overruns may be significantly large. However, establishment of this fact was beyond the scope of this study; therefore, recommended for further studies.

\section{REFERENCES}

[1] M. Emhjellen, K. Emhjellen, P. Osmundsen, "Cost Estimation Overruns in the North Sea", Project Management Journal, PMI vol. 34, no. 1, pp. 23-29, 2003.

[2] H. Chandra, "Management of construction in developing countries: Indian experience", Proceedings of CIB 90 Joint Symposium on Building Economics and Construction Management, Sydney, Australia, vol.5, pp. 211-224, 1990.

[3] S. Morris, "Cost and Time Overruns in Public Sector Projects", Economic and Political Weekly, vol. 25, no. 47, pp. 154-168, 1990.

[4] A.S. Chang, "Reasons for Cost and Schedule Increase for Engineering Design Projects", Journal of Management in Engineering, ASCE, vol. 18, no. 1, pp. 29-36, 2002.

[5] R. Mendelsohn, "The Constructability Review Process: A Constructor's Perspective", Journal of Management in Engineering, ASCE, vol. 13, no. 3, pp. 17-19, 1997.

[6] S.D. Anderson, D.J. Fisher, S.P. Rahman, "Constructability Issues for Highway Projects", Journal of Management in Engineering, ASCE, vol. 15, no.3, pp. 60-68, 1999.

[7] G. Creedy, M. Skitmore, J. Wong, "Evaluation of Risk Factors Leading to Cost Overrun in Delivery of Highway Construction Projects", Journal of Construction Engineering and Management, vol. 136, no.5, pp. 528-537, 2010.

[8] R. Apolot, H. Alinaitwe, D. Tindiwensi, "An Investigation into the Causes of Delay and Cost Overrun in Uganda's Public Sector Construction Projects", Proceedings of $2^{\text {nd }}$ International Conference on Advances in Engineering and Technology, Entebe, pp. 305-312, 2011.

[9] S.M. Vidalis, F.T. Najafi, "Cost and Time Overruns in Highway Construction", Proceedings of $4^{\text {th }}$ Transportation Specialty Conference of the Canadian Society for Civil Engineering, Montréal, Québec, 2002.

[10] C. Kaliba, M. Muya, K. Mumba, "Cost Escalation and Schedule Delay in Road Construction Projects in Zambia", International Journal of Project Management, vol. 27, no. 5, pp. 522-531, 2009.

[11] Ireland's National Roads Authority, "Project Development for Ireland roads", Publications Unit, National Roads Authority, Dublin, 2008.

[12] European Transport Safety Council, "Road Safety Audit and Safety Impact Assessment", Rue du Cornet, Brussels, 1997.

[13] J. Wrisberg, P.K. Nilsson, "Safety audit in Denmark - a costeffective Activity", Danish Road Directorate, Copenhagen, 1996.

[14] A. Arnitis, D. Sevele, M. Nauzere, "Technology of Feasibility Study", Strategy Development, Latvian State Roads, Riga, 2005.

[15] Oregon Department of Transportation, "Road Design Manual", ODoT, Oregon, 2000.

[16] Montana Department of Transport, "Road Design Manual", Montana Department of Transport, Montana, 2008.

[17] Vermont Agency of Transportation, "Highway Project Development Process", Vermont Agency of Transportation, Montpelier, 2008.

[18] C.A.O' Flaherty, 'Highways: The Location, Design, Construction \& Maintenance of Pavements", Butterworth-Heinemann, Malta, 2002.

[19] B. Flyvbjerg, M.S. Holm, S. Buhl, "Underestimating Costs in Public Works Projects: Error or Lie?", Journal of the American Planning Association, APA, vol. 68, no.3, pp. 279-295, 2002

[20] K.C. Sinha, C. Bordat, B.G. McCullouch, S. Labi, “An Analysis of Cost Overruns and Time Delays of INDOT Projects", Publication FHWA/IN/JTRP-2004/07, Joint Transportation Research Program, Indiana Department of Transportation and Purdue University, West Lafayette, Indiana, 2004.

[21] TANROADS, "Mutukula - Muhutwe Road Upgrading Project, Project Completion Report", TANROADS, Dar es Salaam, 2006a.

[22] TANROADS, "Shelui - Nzega Road Upgrading Project, Project Completion Report", TANROADS, Dar es Salaam, $2006 \mathrm{~b}$.

[23] TANROADS, "Nzega - Isaka (Via Tinde) Road Upgrading Project 73km: Final Report”, TANROADS, Dar es Salaam, 2007.

[24] TANROADS, "Mwanza/Shinyanga Border - Tinde Road Upgrading Project: Project Completion Report", TANROADS, Dar es Salaam, 2008a.

[25] TANROADS, "Singida - Shelui Road Upgrading (Package 1: Singida Town - Iguguno), Project Completion Report", TANROADS, Dar es Salaam, 2008b. 
[26] TANROADS, "Singida - Shelui Road Upgrading (Package 2: Iguguno - Sekenke Diversion), Project Completion Report", TANROADS, Dar es Salaam, 2008c.

[27] TANROADS, "Singida - Shelui Road Upgrading (Package 3: Sekenke Diversion - Shelui), Project Completion Report", TANROADS, Dar es Salaam, 2008d.

[28] J. K. Hollmann, L. R. Dysert, "Escalation Estimation: Working With Economics Consultants", AACE International Transactions, AACE International, 2007. 


\section{APPENDIX}

APPENDIX - 1: REASONS FOR TIME OVERRUN ON CASE STUDY PROJECTS

\section{Mutukula - Muhutwe Road Upgrading Project}

- Lack of the survey monuments and incorrect setting out data

- Additional works: bus bays, junctions and vehicular and pedestrians' accesses that were not included in the original design

- Increase in earthwork quantities as a result of incorrect levels of the original design, adverse ground conditions, change in design of some structures, underestimation of some quantities in the original BOQ

\section{Shelui - Nzega Road Upgrading Project}

- Out of date design and survey data

- Additional bus bays, increase on earthworks and rock excavation

- Late payment of some interim certificates

- Reduced production in rainy season

\section{Nzega - Isaka (Via Tinde) Road Project}

- Incorrect design levels

- Carrying out geotechnical investigation and drainage afresh

- Increase in earthworks, rock excavation and drainage facilities

\section{Mwanza/Shinyanga Border - Tinde Road Project}

- Incorrect design levels

- Carrying out geotechnical investigation and drainage afresh

- Increase on number of bridges and culverts

- Increase on earth works, rock excavation and rock fill

- Demolishing and replacing the already installed culverts after noting that some were wrongly located in the design and others were undersized

Singida - Shelui Road Upgrading (Package 1: Singida Town - Iguguno)

- Incorrect setting out data and alignments, both horizontal and vertical

- Addition of nine pipe culverts and two box culverts

- Increase in earthworks

- Introduction of gabion boxes to protect embankments that were raised beyond the expected height

- Additional works for weighbridge, replacement of box culvert for the bridge in Iguguno Township, Boma and Mandewa roads $(3.32 \mathrm{~km})$ [These items were completely new, therefore, change in project scope]
Singida - Shelui Road Upgrading (Package 2: Iguguno Sekenke Diversion)

- Incorrect setting out data and alignments, both horizontal and vertical

- Additional works: eight bus bays and vehicular and pedestrians' accesses that were not included in the original design

Singida - Shelui Road Upgrading (Package 3: Sekenke Diversion - Shelui)

- Incorrect setting out data and alignments, both horizontal and vertical

- Additional works: stone masonry walls to retain materials at bridges, approach slabs to all bridges, bigger corrugated metal pipe culverts at some junctions, protection works for bridges, super elevation over bridges on curves and trapezoidal ditches along undercut sections.

\section{APPENDIX - 2: REASONS FOR COST OVERRUN ON CASE STUDY PROJECTS}

\section{Mutukula - Muhutwe Road Upgrading Project}

- Increase in work quantities as a result of incorrect levels of the original design, adverse ground conditions, change in design of some structures, underestimation of some quantities in the original BOQ (TShs. 1,394,068,112)

- Additional works including bus bays, junctions and vehicular and pedestrians' accesses that were not included in the original design (TShs. 762,212,910)

- Cost escalation whose item was not included in the original contract price (TShs. 1,367,764,782)

\section{Shelui - Nzega Road Upgrading Project}

- Out of date design and survey data (TShs. $361,579,810)$

- Additional bus bays, increase in cost for earthworks (TShs. 843,110,347)

- Interest on late payment of some interim certificates (TShs. 180,789,905)

- Cost escalation (TShs. 501,140,498)

\section{Nzega - Isaka (Via Tinde) Road Project}

- Additional costs as a result of modifications to the works, updating the BoQ including the new rates for additional works (TShs. 11,732,474,963)

- Additional cost for insurance (TShs. 152,978,881)

- Surfacing equipment standby cost (TShs. 338,545,516)

- Additional cost for performance bond as a result of increased works (TShs. 34,904,293)

- Additional cost for haulage of water for construction (TShs. 272,968,422)

- Cost escalation (TShs. 7,480,986,286) 


\section{Mwanza/Shinyanga Border - Tinde Road Project}

- Additional costs as a result of modifications to the works, updating the BoQ including the new rates for additional works (TShs. 13,773,845,853)

- Additional cost for insurance (TShs. 235,508,730)

- Surfacing equipment standby cost (TShs. 475,135,672)

- Additional cost for performance bond as a result of increased works (TShs. 52,440,447)

- Additional cost for haulage of water for construction (TShs. 108,592,660)

- Cost escalation (TShs. 9,565,264,991)

Singida - Shelui Road Upgrading (Package 1: Singida Town - Iguguno)

- Quantity underestimation on some BoQ items and omission of some items (TShs. 3,207,529,433)

- Additional works for weighbridge, replacement of box culvert for the bridge in Iguguno Township, Boma and Mandewa roads $(3.32 \mathrm{~km})$ [These items were completely new, therefore, change in project scope] (TShs. 2,564,331,114)

- Cost escalation (TShs. 1,179,913,299)

Singida - Shelui Road Upgrading (Package 2: Iguguno Sekenke Diversion)

- Quantity underestimation on some BoQ items and omission of some items and changes in design (TShs. 1,605,887,002)

- Increase in initial estimate of cost escalation (TShs. 275,470,148)

Singida - Shelui Road Upgrading (Package 3: Sekenke Diversion - Shelui)

- Quantity underestimation on some BoQ items and omission of some items and changes in design (TShs. 2,170,911,873)

- Increase in initial estimate of cost escalation (TShs. 2,170,911,873)

\section{APPENDIX - 3: RESULTS OF DISCUSSION WITH CONSULTANTS}

Roundtable discussions were held with engineers in five consulting companies. Generally, consultants were of the opinion that substantial cost and time overruns were in not only road construction projects but in the whole construction industry in general.

\section{Appendix 3.1: Discussed Contributory Factors}

$i$. Topographical Surveys: With regard to the topographical survey problem, the following were noted:

a. In most cases the survey component is always subcontracted to other small companies without adequate supervision and with inadequate payment b. Incompetence of some of the surveyors

c. Low degree of accuracy of survey equipment used

d. Improper adjustments of errors: During survey exercise, there is a maximum closing error above which someone should repeat the whole exercise. However, most surveyors who encounter such a situation never repeat the exercise; instead, they just distribute the error irrespective of how large it is.

e. The duration between design time and start of construction works affects the vertical alignment because of re-gravelling or loss of gravel that takes place after design.

f. Some companies use contoured maps instead of carrying out field works.

ii. Quality of design works: Consultants gave out the following reasons for inadequate design:

a. Lack of capability by the client to review design reports submitted by consultants

b. Some of the projects are given to incompetent companies that are not able to handle the work; as a result, they are deploying part time engineers that always do the work in a hurry, which results in substandard products.

c. Inadequate Terms of Reference for design reviews submitted to consultants. In most cases, consultants review the BoQ and if the design was done some years back, an inflation factor is just applied to the unit cost in order to reflect the current market. It was suggested to include field review so as to incorporate field changes.

iii. Road Safety Audit (RSA): All companies that participated on the discussion agreed that lack of incorporation of RSA work in the design process contributes to design changes during construction stage and therefore recommended it to be incorporated. However, out of the five consulting companies that participated in the discussion, only two declared to have local expertise to carry out the exercise. Those who declared to have no expertise said if TANROADS introduces the exercise, the capacity will be developed too. Their argument was that developing the capacity now is unnecessary as the exercise is not being conducted.

iv. Political pressure: It was noted that in principle the issue of road network development starts by planning that entails ranking several roads according to predefined criteria. It is unfortunate that development of some of the roads does not follow the traditional approach. Instead, politicians pressurize engineers to prepare reports supporting development of the roads and making sure that the route becomes economically viable. Consultants argued that in this top-down procedure, some facilities such as bridges are being omitted in the design in order to make the route economically viable but during construction stage it is 
realised that these facilities are very important and inevitable and therefore be included.

v. Cost escalation: About $20 \%$ of all consultants who participated in the discussion had the understanding that escalation cost is within the contingency, which is contrary to the state-of-the-practice [28]. Before Justice Warioba's report on corruption, there existed two types of contingencies namely physical contingency that used to compensate for the underestimation and price contingency that used to cater for cost escalation. The report was against even physical contingency as it was identified as one of the major sources of corruption. Upon arguing to the treasury section, only physical contingency was allowed. However, recently the treasury section has realised the importance of price contingency and therefore allowed its inclusion in current cost estimates.

vi. Corruption: All consultants agreed on the prevalence of corruption. This was identified as the main factor that leads to awarding projects to incompetent consulting companies. However, establishment of the evidence of corruption is beyond the scope of this study, this is therefore termed as 'perceived corruption'.

vii. Absence of road geometric design manual: All consultants who participated in the discussion were aware that the absence of a complete geometric design manual is a problem. They further argued that the available type-written draft which was prepared in the early 1980s and published in late 1980s is incomplete and obsolete compared to manuals of other countries as it lacks some important sections particularly the one that shows the stages of design and the deliverables together with their reviews and approvals. On the other hand, the Southern Africa Transport and Communication Commission (SATTC) manual that is usually referred to in design contracts is not familiar even to some TANROADS officials.

viii. Unrealistic Design project duration: Consultants revealed that sometimes the duration for the design of the project is not enough; as a result, the exercise is performed in a hurry that may lead to substandard outputs. The situation is worse if there is no prior preliminary design.

\section{Appendix 3.2: What Should be Done to Alleviate the Problem}

It was suggested that in order to alleviate the problem, the Design section at TANROADS headquarter needs to be overhauled. Particular improvements could be made to the current review process of design reports, especially geotechnical/materials investigation and topographical survey. Several options were pointed out such as: hiring additional independent consultants to review design documents; establishing a review of consultant's performance with regard to number and type of change orders occurring on projects so that future design contract awarding process could consider that; and, adding more review requirements for consultants.

In addition, the client needs to have counterparts in the design team so as to make sure the field work is thoroughly done. This would help to plug the loopholes of some consultants to cut corners. However, it was suggested that this process would require a review of the staffing level at TANROADS.

\section{APPENDIX - 4: RESULTS OF DISCUSSION WITH TANROADS OFFICIALS}

\section{Appendix 4.1: Discussed Contributory Factors}

$i$. Lack of experts: With regard to experts, officials in the design section explained that TANROADS has experts in all fields except a hydrologist. According to the head of the design section, during the design work, facilities such as drainage ditches and the like are just provided through experience. However, this was thought to be the source of drainage facilities problem observed on several projects.

ii. Road Safety Audit (RSA): TANROADS officials informed the author that the exercise is being carried out for only completed projects - which is contrary to the state-of-the-practice. According to their knowledge, this activity is for completed projects.

iii. Cost escalation: Those works that were tendered immediately after Justice Warioba's report on corruption did not include escalation cost item in the budget as by then it was strictly perceived to be a major source of corruption. However, after the matter was well explained and understood by decision makers, current projects are now providing for cost escalation, though its estimation is still a big challenge taking into consideration that no any serious research on the matter has been done.

iv. Use of outdated designs: It was explained that once a loan is secured, one of the requirements is to immediately start the construction. Although the client is aware of the consequences, he is still forced to adopt outdated designs on delayed projects.

v. Insufficient number of staff: The head of Design section declared that there is a problem of having few engineers compared to the available work-load. Under this situation, TANROADS is not able to send counterparts in the field to participate in the design work. This also affects the design review exercise as staff are always very busy. The plan is to have more engineers employed and to commission the design review task to independent consultants instead of having it done in-house. 
vi. Topographical survey problem: TANROADS iii. officials declared topographical survey a burning issue. The most suspected cause is either the methods adopted by consultants or the use of GPS with unacceptable accuracies. TANROADS has now decided their surveyors will be involved in this activity on the field.

vii. Road geometric design manual: TANROADS officials declared the existing draft manual to be obsolete. However, they are aware of its importance and a new one is under preparation and was expected to be out by July 2010 .

viii. Tracking causes of repeated design problems: One of the ways of eliminating problems that are frequently occurring is to track their causes. According to the head of the design section, it is unfortunate that TANROADS does not have such a mechanism in place.

ix. Road design process: The head of the Design section explained that there are no specific stages before reaching the final detailed design. However, in most cases feasibility studies and preliminary design is done followed by detailed design. The feasibility study and preliminary design involves economic analysis, which is done after identifying the preliminary route with its associated cost and environmental impact assessment. The detailed design repeats some of the works that were done in preliminary design but in a more detailed manner. However, some of the projects never go through the feasibility study and preliminary design if they can be justified by reasons other than economic.

$x$. Political pressure: This was declared as one of the problems affecting the quality of design. TANROADS officials pointed out that if there is political pressure, project planning processes are always done in ad-hoc and lackadaisical approach and sometimes detailed project reports as well as feasibility study reports are either not prepared at all or are poor, prepared only as a formality.

Appendix 4.2: Measures to be taken by TANROADS to Reduce Design Problems

Officials revealed that TANROADS is planning to undertake the following in order to reduce inadequate design problem:

i. To increase seriousness in reviewing designs submitted by consultants

ii. To have a watch-dog on site who will ensure personnel whose Curriculum Vitae were submitted in the proposal are the ones doing the work in the field. It is considered that one of the problems observed in the design works is the involvement of semi-skilled/incompetent personnel.
Consultant to insure their works so that any mistakes observed later is covered by the insurance. 